\title{
Desfazendo os nós semióticos em Nossa Senhora Desatadora de Nós
}

Cristiane Wosniak Universidade Federal do Paraná/UFPR 


\section{Resumo}

Este artigo se propõe a investigar as relações de persuasão e de interpretação de uma imagem pictórica de Nossa Senhora Desatadora dos Nós, na forma de folheto ou gravura, destinada à reprodução e distribuição em massa, bem como preservação da memória e da comunicação de um discurso religioso sob a perspectiva de análise deste discurso. A imagem sincrética selecionada pode ser examinada sob os domínios̀da sèmiótica visual é portanto, fundamentar-se na semiótica greimasiana. No percurso gerativo do sentido irão se determinar os dispositivos que o onunciàdór estả beleçe e o enunciatário interpreta a partir do texto não-verbal em seu plano de expressão relacionado ao seu plano de conteúdo.

\section{Palavras-chave}

semiótica visual, imagem, sincretismo, discurso, memória

\section{Abstract}

This article propose to investigate the relations of persuasion and interpretation about a pictorial image of Nossa Senhora Desatadora dos Nós, in form of pamphlet or carving destined to mass reprodution and distribuition, beneath the perspective of speech analysis. The sincretical image select can be examineted to dominion of visual semiotic, and hence, its grounding to be in greimasian semiotic. In this generator pathway of meaning will be determined the gadgets which the enunciator set up and the enunciatair interpret breaking of the not verbal text in its expression plan associated with its content plan.

\section{Key words}

visual semiotic, image, syncretism, speech, memory 
$\mathrm{A}$ intenção deste artigo é proceder a uma análise semiótica da imagem de Nossa Senhora Desatadora dos Nós ${ }^{1}$ como um discurso em que se relacionam, no percurso gerativo do sentido, os planos da expressão e do conteúdo. A opção pela teoria semiótica desenvolvida por A. J. Greimas e pelo grupo de Investigações Sêmio-lingüísticas da Escola de Altos Estudos em Ciências Sociais deve-se ao fato de que esta escola preocupa-se com a teoria do texto, e como neste artigo o enfoque é descritivo, buscou-se em Greimas a afirmação de que a descrição é uma construção. Não se pretende, entretanto, construir um modelo ontológico com a semiótica greimasiana, mas um simulacro metodológico da produção e da compreensão da significação. Além de Greimas, salientam-se as contribuições de L. Hjelmslev que demonstrou ser possível examinar o plano do conteúdo separado do plano da expressão, rompendo as barreiras entre o enunciado e a enunciação. Também é oportuno lembrar que o sistema semisimbólico, base da semiótica plástica desenvolvida por Jean-Marie Floch, irá oferecer condições para avaliar categorias plásticas no plano da expressão e categorias semânticas no plano do conteúdo, identificáveis na gravura em questão e, com isto, permitir que se possa ir um pouco além dos referentes discerníveis numa mera

1 Já nos anos 60, Roland Barthes em seu artigo A Retórica da Imagem, analisando de forma semiológica a imagem fotográfica, chega a conclusões que permitem visualizar a foto como traço do real, suscitando fenómenos de crença inéditos até o momento de sua invenção. Barthes conclui que "não apenas acreditamos na foto, na realidade do que a foto representa, mas esta última produz uma verdadeira revelação sobre o objeto representado." (Aumont, 2004, pp. 127128). Traçando um paralelo com a gravura impressa (santinho), pode-se, por analogia, pressupor o mesmo efeito de identificaçāo entre estas duas formas de mídia. 
descrição de elementos isolados, daí a análise do texto e do contexto: os 'nós feitos e os nós desfeitos' em Nossa Senhora Desatadora dos Nós.

\section{O texto como enunciado}

Segundo Barros (1997, pp 7-8), a semiótica tem por objeto de estudo o texto : a semiótica procura descrever e explicar o que $o$ texto diz e como ele faz para dizer o que diz. Para a autora, um texto pode ser definido por duas formas que se complementam, ou seja, como objeto de significação, do qual se procede a análise estrutural ou interna do texto ou como objeto de comunicação entre sujeitos, que se insere entre os objetos culturais de uma sociedade e, deste modo, sendo determinado por formações ideológicas específicas. Neste último caso, o texto precisa ser examinado em relação ao contexto sócio-histórico que o envolve e relacionar-se também com o perfil do destinatário desta recepção, que em última instância irá lhe atribuir este ou aquele sentido.

Considerado como texto artesanal, a imagem em folhetos (santinho) é feita para a contemplação. Segundo Santaella (2001, pp.174-75), por haver nela sempre algo de sagrado, uma nostalgia do divino, a imagem artesanal convida o receptor a um impossivel contato imediato sem mediações, ao mesmo tempo em que produz um afastamento que é próprio dos objetos únicos.... Neste sentido, sempre é oportuno lembrar da questão da aura, abordada por Walter Benjamim (1964) em A obra de arte na época de sua reprodutibilidade técnica, teorizando questões relativas ao valor cultural, autenticidade e unicidade (aura) da obra de arte. Não obstante as diferenças, se levarmos em conta o caráter da (re)produção manual, acentuadamente matérica, a gravura/folheto, embora de forma artesanal, já começara a antecipar, no século XVIII e XIX, o caráter reprodutor massivo (cultura de massa) da fotografia. Mas, retornando à questão do texto, A J. Greimas o descreve como a junção do plano do conteúdo com o plano da expressão:

Considerado como enunciado, texto opõe-se a discurso, conforme a substância de expressão - gráfica ou fônica 
- utilizada para a manifestação do processo lingüístico... O texto uma vez manifestado, assumirá a forma de uma representação semântica do discurso. (Greimas, 1979, p. 460)

O texto basta-se a si mesmo. Segundo Landowski (1989, p. 147), Greimas não nega que o conhecimento do mundo possa entrar no processo de apreensão do sentido do texto. Considera, entretanto, este conhecimento desnecessário para sua compreensão. Posteriormente, a semiótica vai evoluir, no sentido de destacar a importância do contexto para a compreensão do sentido. $O$ texto visual a ser analisado, construído de forma bidimensional ou planar, é um objeto significante e, como tal, faz parte de um sistema semiótico, passível de ser analisado e, portanto, verbalizado ou nomeado:

A verbalização da mensagem visual manifesta processos de escolhas perceptivas e de reconhecimento que presidem sua interpretação. Essa passagem do "percebido" ao "nomeado", essa transposição da fronteira que separa o visual do verbal é determinante nos dois sentidos (Joly, 2003,pp. 72-73)

\section{A mensagem e o sentido}

O folheto com a imagem impressa de Nossa Senhora Desatadora dos Nós possui diversos componentes com suas significações específicas e que se articulam uma às outras para produzir a mensagem global. Para Barthes, em seu texto $A$ Retórica da Imagem (1964), a imagem não pode ser confundida com analogia, não sendo apenas constituída do signo icônico ou figurativo. Para o autor, os materiais são: o lingüístico, o icônico codificado e o icônico não codificado. Joly, num estudo das teorias de Roland Barthes, afirma:

dentro da mensagem visual, vamos distinguir os signos figurativos ou icônicos, que, de modo codificado, dão uma impressão de semelhança com a realidade jogando 
com a analogia perceptiva... Vamos designar com o termo signos plásticos os componentes propriamente plásticos da imagem; como a cor, as formas, a composição e a textura. Os signos icônicos e os signos plásticos são então considerádós como signos visuais ao mesmo tempo distintos e complementares. (Joly, 2003, pp. 75-76)

A partir dos postulados de Roland Barthes, em sua 'Retórica da Imagem', é possível compreender a evolução do conceito de ampliação da retórica da linguagem verbal rumo a uma retórica geral, aplicável a todos os tipos de linguagens.

\section{O contexto sócio-histórico da imagem e da mensagem}

Antes de se tornar um folheto impresso (santinho), essa imagem foi concebida sob a forma de uma pintura iconográfica, em 1700 , na Alemanha. O quadro ou painel, originalmente com 1,10 metro de largura e 1,82 metro de altura, encontra-se na capela de St. Peter Am Perlach em Ausburg e foi pintado por Johann Schmittdner, sob encomenda do presbítero da capela que queria uma obra que retratasse a Virgem Maria. A 'mãe de Deus', em seus mais de dois mil títulos, é retratada por Schmittdner como Maria Knotenlöserin, ${ }^{2}$ inspirandose nos escritos de um bispo de Lyon, no século III e que mais tarde se tornaria mártir da Igreja Católica Apostólica Romana: 'Eva por sua desobediência atou o nó da desgraça para o gênero humano; Maria por sua obediência, o desatou...' Estudando-se a vasta iconografia católica, observa-se que a imagem da Virgem Maria é sempre lembrada como a consoladora nas angústias e como fortaleza nas perseguições. Maria é a medianeira da graça divina; sua imagem representa a mediação entre o céu e a terra. Tão logo a pintura foi apresentada à comunidade, não demorou a se tornar objeto de culto, mas restringindo-se inicialmente à Alemanha. Relatos de seus feitos

2 Segundo a tradução alemã: Knotenlöserin: ( $k$ not = nó e löser $=$ desatar $)$. 


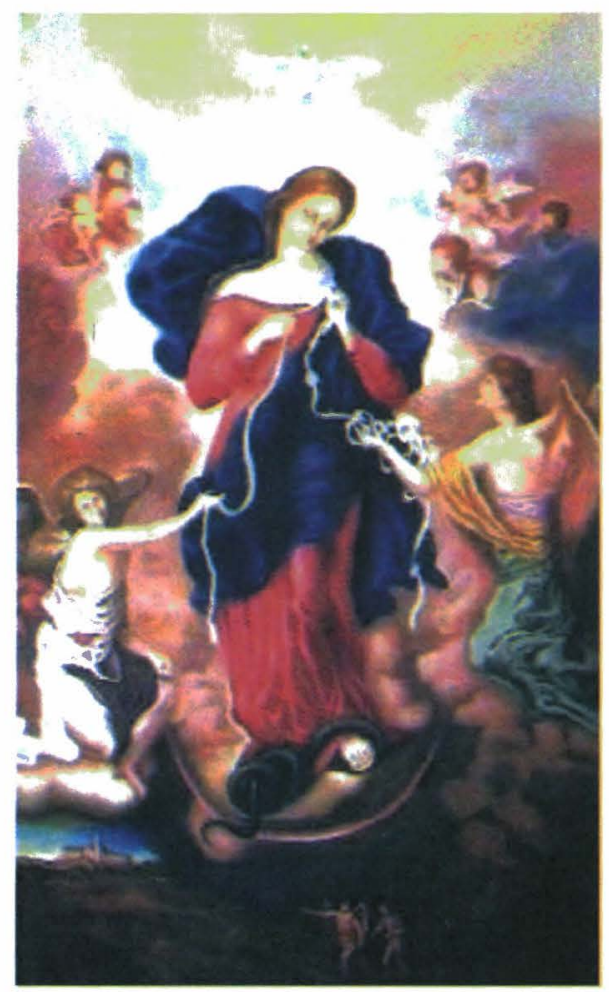

Nossa Senhora Desatadora dos Nós

(milagres) percorreram países, e no século $\mathrm{XX}$, na década de oitenta, penetra na Argentina. No Brasil, somente no século XXI esta imagem começa a movimentar uma legião de devotos e cultos em seu nome. Símbolo do sofrimento e da fé, pois Maria perdeu o próprio filho, alimentou ainda mais sua crença, tornandose um pilar e uma fortaleza para os próprios apóstolos de Cristo. A Nossa Senhora Desatadora dos Nós ficou conhecida como a santa que intercede ao Pai, com a finalidade de resolver os problemas de difícil solução (nós) de seus devotos: também é conhecida por conceder inúmeras graças no casamento e promover a reconciliação de famílias, razões que confirmam o motivo de uma grande procura de fiéis católicos ou em vias de conversão, em relação às imagens (santinhos) com a oração a ela dedicada. As imagens de santos e anjos tornaram-se extremamente comuns no ocidente, como forma de divulgação em massa de um discurso religioso, perpetuando a memória e contribuindo para a disseminação e, segundo Parissot (1989), também para a 'espetacularização' de um discurso religioso da Igreja que enaltece valores centrados na crença, na fé e na eterna cruzada do bem contra o mal. O suporte da imagem - o folheto com a gravura de Nossa Senhora Desatadora dos Nós - dirige-se a um tipo de receptor/ enunciatário particular e ideal, constituído de ambos os sexos, casados ou não, com problemas familiares, de classe média a baixa, filiado 
(fiel) religiosamente ao cristianismo ou em vias de conversão ao marianismo, ou seja, uma das manifestações do catolicismo em voga no Brasil desde o período colonial. Por sua figura conciliadora, maternal e que evoca paciência e doçura, ao invés de temor e culpa, a imagem de Maria tornou-se um poderoso instrumento da catequese e do discurso da conversão religiosa.

\section{O significante em Nossa Senhora Desatadora dos Nós - nós feitos}

O texto é a unidade da manifestação. É olugar em que os diferentes níveis (fundamental, narrativo e discursivo) do agenciamento do sentido se manifestam e se dão a ler. A leitura descritiva da imagem em questão apresenta uma figura feminina que ocupa a posição central do enquadramento que consiste num folheto com as seguintes dimensones originais: $10 \mathrm{~cm}$. de comprimento por $7 \mathrm{~cm}$. de largura. A reférida figura porta um traje vermelho e branco e um manto azul característico das figuras iconográficas. $O$ detalhe que diferencia este manto dos demais mantos retratados nas imagens de Măria é o fator 'movimento', dando a impressão de vida própria: seu manto aparenta ser agitado por Aquele que dá a vida. Nesta representação da Imaculada Conceição, ela paira, flutuando entre o céu e a terra, numa posição intermediária. A figura aparenta também estar 'revestida' de luz branca que emana a partir da perspectiva central da figura de uma pomba branca com as asas abertas, que paira sobre sua cabeça. Ao redor da pomba branca, observa-se a coloração amarelo-dourada e ao fundo tons de azul, como o céu da paisagem. Não muito nítida, é a presença indelével de um semi-círculo de estrelas que fazem uma espécie de moldura ou coroa para a cabeça da personagem. Ao invés de uma auréola, símbolo corriqueiramente encontrado nas figuras religiosas, aqui se apresentam doze estrelas brancas. Sua cabeça pende levemente para o lado esquerdo a segurar e manusear uma fita branca que lhe é ofertada por um anjo que ocupa a posição lateral direita da gravura. Este anjo, envolto em tecido verde e 
dourado, deixa antever, metonimicamente, um pedaço de sua asa; encontra-se pairando entre o céu e a terra, aparentando entregar ou oferecer à figura feminina uma faixa branca na qual se observam muitos nós, maiores e menores, juntos e separados: Do lado esquerdo da figura feminina, em oposição ao anjo da lateral direita, encontrase uma outra figura angelical, envolta em tecidos brancos, deixando antever suas asas: esta figura encontra-se nitidamente ajoelhada e olha atentamente à frente, como a 'encarar' o destinatário ou observador da pintura. Esta figura angelical ajoelhada segura e parece mostrar a mesma faixa ofertada pelo anjo da direita, mas agora com os nós desfeitos, pois a faixa está reta. $\mathrm{Na}$ altura da cabeça da figura feminina, de ambos os lados, percebe-se a presença de um grupo de pequenas figuras aladas, com o aspecto semelhante a crianças, bebês, emaranhados em densas nuvens brancas, azuis, amarelas e róseas; estas figuras aparentam observar o 'trabalho' da figura feminina em desatar os nós da faixa branca. Sob o manto vermelho da figura feminina, percebe-se um pé descalço a esmagar a cabeça de uma cobra negra enrodilhada, que aparece delimitada por uma espécie de semi-círculo lunar. Na parte inferior da gravura, observa-se uma cena em escala de perspectiva muito menor que o restante da gravura. Sobre um fundo extremamente escuro, destacam-se duas figuras: a de um anjo com asas e a de um homem caminhando em direção a uma colina onde parece encontrar-se a imagem de uma igreja. $O$ anjo aponta para esta direção e conduz a figura masculina. Entre eles, observa-se de forma pouco nitida, quase imperceptível, a figura de um cão.

Inicialmente, analisando-se o plano de expressão da imagem de Nossa Senhora Desatadora dos Nós sob a perspectiva de J. M. Floch (1985) - para quem os elementos constituintes de uma mensagem encontram-se no mesmo espaço, no enunciado -, podemos verificar as seguintes categorias semi-simbólicas:

\section{Categoria constitucional cromática}

Tonalidades: branco (coroa de estrelas) $\mathrm{X}$ negro (cobra ou serpente) - associando o branco à luz, ao dia, vida, divino, Bem, e o tom negro às trevas, à noite, escuridão, morte, luto, pecado, Mal. 
Branco (faixa lisa-sem nós) $\mathrm{X}$ negro (cobra ou serpente) - associando a cor branca da faixa à resolução dos problemas, aflições, culpa ou - nós, e o negro associado tanto à cor da serpente quanto à sua forma enrodilhada, sugerindo a trama, a culpa, o pecado original, as 'armadilhas da tentação'.

Branco (pomba branca) X Negro (serpente) - associando a cor branca ao Espírito Santo, Bem, a cor negra ao Demônio, Mal.

Amarelo-dourado (emanação de cor ao redor da pomba branca) X tons negros (paisagem obscura abaixo da imagem da figura feminina) - associando o amarelo-ouro como emanação do divino, do Bem, e os tons negros como emanação das trevas, do sombrio, do Mal.

\section{Categorias relacionais eidéticas}

Formas - humana (santa) X réptil (serpente) - referentes aos personagens representantes do Bem X Mal ; forma da ave (pomba) branca com asas abertas, em expansão $\mathrm{X}$ forma do réptil enrolado, em retraimento e prostrado ou esmagado (serpente)- referentes à força dos símbolos do cristianismo. sobre o anti-cristianismo, esmagado sob os pés da figura central; forma curva ou semi-círculo único de estrelas brancas que contornam a cabeça da santa $\mathrm{X}$ círculos ou circunvoluções descritas pelo 'enrolar em nós' da serpente ao ser esmagada pelos pés da santa - referentes ao discurso da Igreja: o Bem X Mal; a forma da faixa branca com nós maiores e menores, juntos e separados (formas curvas acentuadas) $\mathrm{X}$ a forma da faixa branca lisa, estendida sem nós (formas retas) - referentes aos problemas, angústias e aflições dos fiéis e a resolução destes 'nós' pela intermediação do divino (santa).

\section{Categorias relacionais topológicas}

Orientação: alto (verticalidade) X baixo (horizontalidade) - a figura humana (santa) é percebida como verticalidade/superatividade/ potência e a figura do réptil (mal) como horizontalidade/imobilidade/ impotência; lado direito X lado esquerdo - a faixa na lateral esquerda é percebida como cheia de nós (pecados) e na lateral direita, após a intermediação de Maria, como reta, lisa, sem nós e por conseguinte, livre de problemas, aflições e pecados; 
Dimensão: grande/alta X pequena/baixa - a figura humana (santa) é percebida como simbolicamente superior e a figura do réptil (mal) como simbolicamente inferior; aberto/expansão X fechado/ retração - a figura da pomba branca (Espírito Santo) é percebida como expansiva e dominante em seu posicionamento superior em oposição ao réptil, contraído em sua posição inferior.

Relacionando-se as categorias do plano do conteúdo com as do plano da expressão, teríamos o seguinte esquema:

\section{BEM X MAL}

figura humana (santa) $\mathrm{X}$ figura do réptil (serpente)

figura da ave (pomba branca $X$ figura do réptil (serpente)

verticalidade/potência $\mathrm{X}$ horizontalidade/impotência

grande/alto/céu X Pequeno/baixo/terra

fita reta sem nós $X$ fita curvilínea com nós coroa de estrelas brancas (divino) $\mathrm{X}$ serpente/negra (anti-divino) nós desfeitos pela crença(oração) $\mathrm{X}$ nós originários do pecado manto azul divino (movimento) $\mathrm{X}$ réptil negro (imobilidade)

\section{Análise do discurso - o percurso gerativo do sentido}

Em Teoria Semiótica do Texto, Barros (1997, pp.10-11) afirma que no nível das estruturas fundamentais é preciso determinar a oposição ou as oposições semânticas a partir das quais se constrói o sentido do texto. Na imagem de Nossa Senhora Desatadora dos Nós, a categoria semântica fundamental é: o Bem/obediência/crença/ausência dos 'nós'obtidos pela oração ou intermediação da Virgem Maria, tendo como oposição simbólica o Mal/desobediencia/pecado/'nós' obtidos pela culpa e a não conversão. Esta oposição é perceptível de diferentes maneiras: - Bem é representado pelo personagem central da Senhora Desatadora dos Nós, auxiliada por um séqüito de anjos maiores e menores, sendo que dois deles também seguram as pontas da simbólica faixa branca. Numa dupla ação, a santa, ao mesmo tempo em que desata os nós 
ofertados pelo anjo dá direita, esmaga sob seu pé a ameaça e a presença do mal. O Mal é representadó pélo réptil negro, ou serpente, que com suas 'enrolações' tenta dissuadir os verdadeiros crentes de permanecerem ou comungarem as graças divinàs. A fé na resolução dos problemas (pecados) é representada (está ancórada) no símbolo icônico da faixa branca dividida em duas partes: na lateral direita, os nós aludem ao pecado original, às angústias e aflições dos mortais e na lateral esquerda aludem à dissolução destes nós, pelo princípio da fé, da oração e da crença incondicional na intermediação de Maria junto a Deus. O que confere o aspecto divino à criatura feminina central são outros dois símbolos icônicos: a coroa de doze estrelas brancas representando as doze tribos de Israel e o número de apóstolos por quem, após a morte de Jesus, foi chamada de mestra nas dúvidas, consoladora nas angústias e fortaleza nas perseguições e a pomba branca de asas abertas, simbolizando a presença do Espírito Santo, vértice do dogma da Santíssima Trindade. Também Barros (1997, p. 11) afirma que as categorias fundamentais são determinadas como positivas ou eufóricas e as negativas como disfóricas. No texto visùal analisado, a serpente negra enrolada e os nós na faixa branca da lateral direita são disfórićos e associados à imanênćia do Mal, do estado de pecado original advindos desde Eva, da corrupção, dos problemas, das aflições e angústias que cerceiam o homem. As figuras da santa e da pomba branca, a presença dos anjos e a faixa branca reta sem nós são associadas ao triunfo da fé, da oração e da intermediação da Imaculada Conceição.

No nível das estruturas narrativas, observa-se a oposição de valores, ou seja, o sujeito (Virgem Maria ou Nossa Senhora Desatadora dos Nós) negando a manipulação e os nós impostos pelo anti-sujeito (serpente enrolada). O sujeito, para cumprir o acordo tácito anterior de fidelidade, humildade, crença e intermediação, como 'mãe amorosa que socorre os filhos nas horas aflitas', combate a tentação dọ anti-sujeito e dẹ seu nós, esmagando-o sob seus pés, ao mesmo tempo em que desata os nós por ele impetrados. O compromisso com o discurso religioso e divino é mantido e reforçado pela presença do anjo da esquerda, que metaforicamente encontra-se ajoelhado, mostrando o 'efeito da faixa reta sem nós' e apelando para o destinatário, visto que ele olha fixamente para 'fora da imagem pictórica', numa espécie de 'enunciação enunciada', 
ao anunciar exatamente o princípio básico da doutrinação ou catequese: somente pela fé e pela oração, os nós do pecado e das dúvidas poderão ser desfeitos pela medịação do divino. A presença da pomba branca e da coroa de estrelas, em substituição à auréola, qualificam o sujeito (santa) como divino e a serpente como símbolo do mal; trata-se de icones socioculturalmente, reconhecidos e, assim, a imagem sincretiza sujeitos de fazeres contrários. O desatamento de um nó em particular também é ilustrado na imagem. Na extremidade inferior da gravura, observa-se um anjo apontando e guiando um homem ao alto de uma colina onde se encontra o símbolo de uma igreja. Alguns autores e maioria dos sites católicos apostólicos afirmam que o pintor com esta alegoria alude à história de Tobias $(6,13-19)$ no Velho Testamento: após empreender uma penosa viagem, Tobias conhece Sara, que já havia se casado sete vezes e todos os seus maridos morriam na noite de núpcias, visto que um demônio dela se enamorara Como Sara fora prometida por Deus a Tobías, eles se casam, ele sobrevive e volta à casa de seu pai. Talvez nesta ilustração de uma cena bíblica esteja uma alusão ao fato de que para dois corações realmente se encontrarem há que se desatarẹm, primeiramente, muitos nós, e que, para isto, a bênção do sagrado matrimônio da Igreja (apontada pelo anjo) e da intermediação da fé e dà oração sejam condições inquestionáveis...

A última etapa do percurso gerativo do sentido é ó nível das estruturas discursivas. Em primeiro lugar, na imagem de Nossa Senhora Desatadora dos Nós, projeta-se uma espécie de narrador em $3^{\mathrm{a}}$ pessoa: trata-se do discurso do cristianismo, da conversão e da exemṕlificaçãó da fé e da crença incondicionais, através do próprio sacrificio (Maria perde seu filho e mantém sua fé) è da negação do Mal para atingir-sè a salvação, o Bem. O sujeito (santa) torna-se mediador da mensagem, o portador ida 'boa nova - ausência de nós'. Determina-se o sujeito da manipulação e da dissimulação (serpente) como mensageiro e também portador de um outro discurso: 0 do anti-cristianismo, dos nós do pecado e, portanto, representante do Mal: Para se perceberem as estratégias da enunciação, devem-se buscar as 'pistas' no enunciado. Por meio do processo que na semiótica greimasiana denomina-se embreagem, procuramos as marcas que nos possibilitam o entendimento do processo. Isto acontece pela reiteração no texto. Assim, observa-se que no 
próprio enunciado têm-se quatro sujeitos enunciadores que desembreiam o sujeito discursivo, pois se pressupõe no enunciado um Eu para desfazer os nós (mediação), um outro $\mathrm{Eu}$, ou melhor, um anti-Eu para originalmente atar os nós, e um Você a quem é dirigida a mútua enunciação. Entretanto, observa-se uma espécie de auxílio ou reforço da mensagem do sujeito, que se faz pela enunciação enunciada deliberada do anjo da lateral esquerda, ajoelhado e mostrando os efeitos benignos da conversão, da fé, da intervenção de Maria. Por meio de sua atitude (ajoelhar-se em sinal de reverência, adoração e oração) ele conduz e reforça a mensagem do Eu sujeito principal. Assim, os sujeitos eufóricos oferecem a dissolução dos nós pela fé e oração; o anti-sujeito disfórico oferece os nós da dúvida e do pecado. Você, o sujeito a quem a mensagem é dirigida, tem a opção do livre arbítrio: querer ou não querer desfazer os nós (a mensagem principal). O sujeito pressuposto que desata os referidos nós, por sua atitude de combate, força e potência sobre o Mal, mantendo serena e humilde postura, caracteriza o procedimento de persuasão e de apresentação da motivação central - a resolução de problemas de difícil solução, através da oração e da fé. $\mathrm{O}$ enunciador do folheto com a imagem de Nossa Senhora Desatadora dos Nós, ao instalar as projeções da enunciação, em pessoa, espaço e tempo, cria efeitos de atualidade e de verdade, baseados em fatos ocorridos em um momento de referência pretérita e alhures, como os relatos dos feitos e milagres atribuídos à figura da santa. Assim se apresenta o simulacro discursivo do enunciador e enunciatário explícitos.

\section{O enunciado e a enunciação}

Ao analisar o texto visual (santinho) como um discurso religioso, doutrinário e, portanto, persuasivo, parte-se do pressuposto de que algo será comunicado a alguém de alguma forma e com alguma intenção. $\mathrm{O}$ esquema básico de comunicação proposto por Roman Jakobson (1969) prioriza a articulação da mensagem e seus fatores na dimensão horizontal/ sentido linear: destinador ${ }^{\circledR}$ destinatário. Esta tendência limitante do esquema de Jakobson foi questionada por Greimas e Courtés, cuja semiótica considera que a comunicação se aproxima muito mais de 
um fazer-crer (persuasão) e de um fazer-fazer (manipulação) do que de um fazer-saber; pressuposto fundante do esquema de comunicação tradicional. (Nascimento, 2002, p. 63)

Neste sentido, Jacques Fontanille irá propor um novo esquema, no qual a comunicação abandona a centralização de um sentido linear/ horizontal para implicar-se na enunciação e no enunciado por ela produzida. Neste ato (jogo) enunciativo além do texto (enunciado) há de se pressupor o contexto (enunciação). Assim, segundo Nascimento (op. cit. p. 66), descrever a significação de um enunciado é descrever sua enunciação, ou seja, propor uma representação do surgimento deste enunciado no contexto dado: $\mathrm{Na}$ representação esquemática de Fontanille, podem-se verificar os pressupostos desta afirmação:

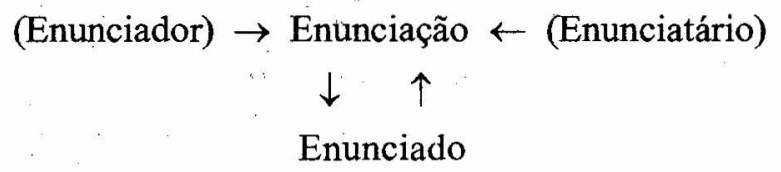

Ainda em Nascimento (op. cit. pp. 67-68), observamos a explicação do funcionamento deste esquema, ou seja, do ato enunciativo, processo ativo que ocorre não só no sentido horizontal, mas também pressupõe a verticalidade: o eixo da comunicação a que a semiótica greimasiana atribui um valor sintagmático, articula no sentido horizontal (destinador/emissor e destinatário/receptor). Já o eixo da produção, a que se atribui um valor paradigmático, articula no sentido vertical (sujeito/da enunciação e objeto/enunciado). $O$ ato de leitura e construção de sentido ou significado ocorre em ambos os sentidos (cima/baixo e baixo/cima) no eixo vertical, segundo o processo descrito:

A passagem da enunciação para o enunciado se efetua graças a um procedimento denominado desembreagem que permite que se projete para fora desta instância tanto os actantes do enunciado quanto as coordenadas espaçotemporais (a pessoa, o espaço e o tempo ou em termos semióticos, o eu, o aqui e o agora) [...] Mas como o que nos é dado é senipre o enunciado, nunca a enunciação - 
sempre pressuposta - o caminho que se faz inicialmente é inverso àquele que se apresentou acima e é levado a efeito pelo mecanismo da embreagem. Esta permite que, a partir do enunciado dado, se tenha acesso, por pressuposição, ao lugar imaginário-transcedental da enunciação. (Nascimento, 2002, pp. 67-68)

As leituras abstratas do enunciado caracterizam-se pela oposição relacional de fatores que separam, na imagem visual, o Mal do Bem:

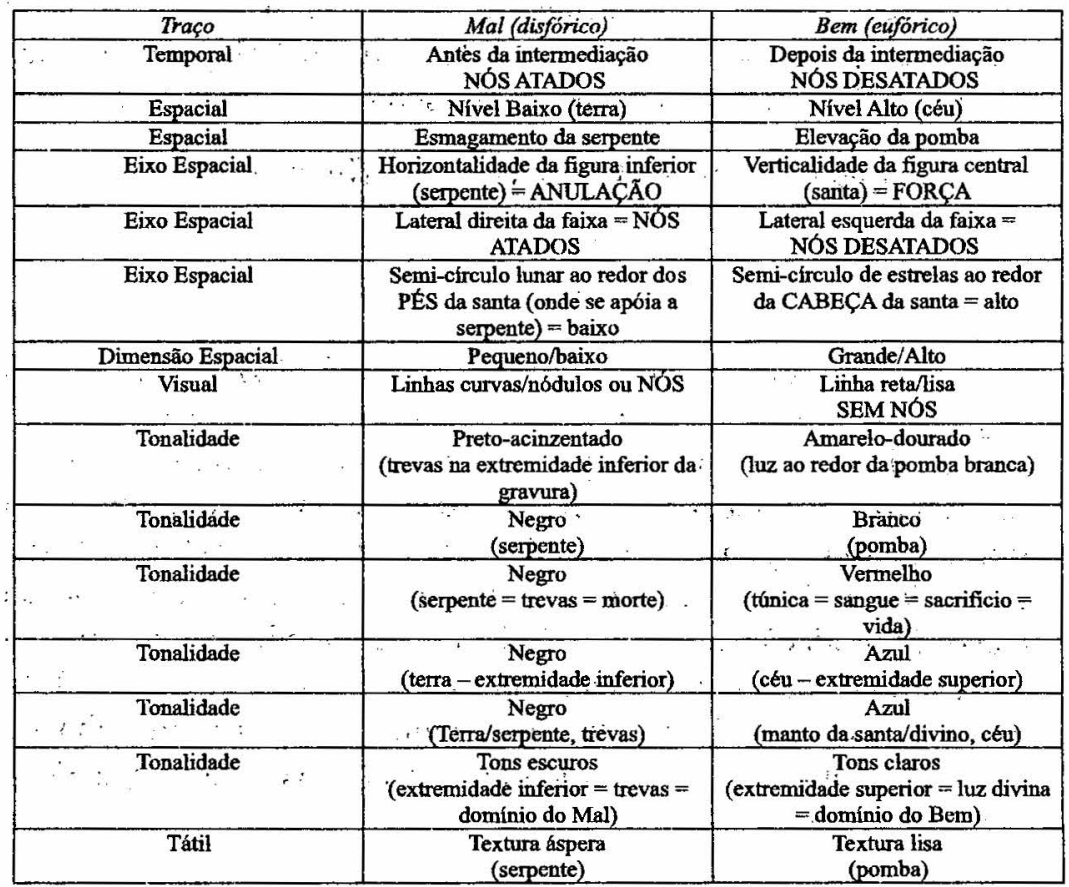

\section{O significado em Nossa Senhora Desatadora dos Nós - nós desfeitos}

O folheto com a imagem visual de Nossa Senhora Desatadora dos Nós apresenta-se como uma gravura em que o personagem central, 
identificado como a santa, devido à presença dos símbolos icônịcos, da coroa de estrelas e da pomba branca (Espírito Santo) sobre sua cabeça, além da presença dos anjos, segura e manuseia (desfaz os nós) uma faixa branca ofertada por um anjo à sua direita, simbolizando o pecado original, os pecados cotidianos e suas conseqüências, enquanto outro, à sua esquerda, segura a mesma faixa em que os nós foram desfeitos após sua intervenção. A figura central, pairando etérea, entre o céu è a terra, ainda esmaga sob o peso de seu pé esquerdo a cabeça de uma serpente negra enrodilhada e apoiada numa espécie de superficie semicircular como uma lua, como sinal de volubilidade. Seu manto azul, num instantâneo de 'movimento', invoca o simbolismo da glória que reveste a 'rainha e mãe do céu'. Na extremidade inferior da gravura, retrata-se a saga bíblica de Tobias e Sara que vencem o mal, pela intervenção divina.

A simples presença metafórica da pomba branca, dos anjos $\mathrm{e}$ da serpente, nesse enunciado, já remete a uma intertextualidade por estilização numa relação contratual, cultural e social com o cristianismo e, em específico, com a religião católica apostólica romana que cultua tais imagens. Segundo Bertran (1985, p. 412), a estilização pode ser polêmica ou contratual. E ainda acrescenta: a estilização é $a$ reprodução do conjunto dos procedimentos do discurso de outrem, isto é, do estilo de outrem. Fica claro que os signos icônicos ou figurativos ${ }^{3}$ estão na imagem por algo mais que eles próprios, estão presentes pelas conotações que evocam. Assim, observamos no folheto ou gravura os seguintes signos: pomba branca, coroa de estrelas brancas, aura de luz branca, manto azul, túnica vermelha, faixa branca com nós, sem nós, meia lua, serpente negra, pé descalço, anjo apontando para uma igreja, anjo ajoelhado, luz amarela-dourada, como representações de objetos ou fragmentos de imagens socioculturalmente determinados.

Na realidade, afirma Joly (2003, pp.104-105), esse tipo de representação é eminentemente sinedótico ou metonímico, isto é, só vemos partes de elementos que ali estão para designar o todo

3 Os signos figurativos ou icônicos segundo Martine Joly (2003), são os signos analisados dentro da mensagem visual, de forma codificada, dando uma impressão de semelhança com a realidade, jogando com a analogia perceptiva e com os códigos de representação herdados da tradição de representação ocidental. 
por contigüidade... Podem-se descrever estes elementos associativos da seguinte maneira:

\begin{tabular}{|c|c|c|}
\hline Significantes Icônicos & Significados de $1^{\circ}$ Nivel & Conotações de $2^{\circ}$ Nível \\
\hline $\begin{array}{c}\text { Figura feminina descalça } \\
\text { com túnica vermelha e } \\
\text { manto azul }\end{array}$ & Mulher com traje estilizado & $\begin{array}{c}\text { Santa } \\
\text { Virgem Maria } \\
\text { Representação do Bem } \\
\text { Fé/crença/devoção } \\
\end{array}$ \\
\hline $\begin{array}{l}\text { Figura feminina desfazendo } \\
\text { nós de uma faixa branca }\end{array}$ & Mulher desfazendo nós & $\begin{array}{c}\text { Nossa Senhora Desatadora } \\
\text { dos Nós }\end{array}$ \\
\hline $\begin{array}{c}\text { Pomba branca de asas } \\
\text { abertas }\end{array}$ & Ave & $\begin{array}{c}\text { Espírito Santo } \\
\text { Divino } \\
\text { Santíssima Trindade } \\
\text { Cristianismo } \\
\text { Representação do Bem } \\
\text { Fé/crença/devoção } \\
\end{array}$ \\
\hline Serpente negra enrodilhada & Réptil & $\begin{array}{l}\text { Demônio-inferno } \\
\text { Anti-cristianismo } \\
\text { Representação do Mal } \\
\text { Pecado original }\end{array}$ \\
\hline Coroa de estrelas brancas & Adereço & $\begin{array}{c}\text { Representação do divino } \\
\text { Santo ou Anjo } \\
\text { Celestial } \\
\text { Pureza }\end{array}$ \\
\hline Pés descalços & Ausência de calçado & $\begin{array}{l}\text { Segurança/fé } \\
\text { Humildade }\end{array}$ \\
\hline $\begin{array}{c}\text { Faixa branca com nós atados } \\
\text {. }\end{array}$ & Nós & $\begin{array}{c}\text { Pecado original } \\
\text { Culpa } \\
\text { Aflições, problemas, brigas } \\
\text { Dificuldades } \\
\end{array}$ \\
\hline Faixa branca sem nós & Faixa branca & $\begin{array}{c}\text { Crença/fé/oração } \\
\text { Absolvição } \\
\text { Resolução de problemas }\end{array}$ \\
\hline Túnica vermelha & veste & $\begin{array}{c}\text { Sacrifício/sangue } \\
\text { Representação do divino } \\
\end{array}$ \\
\hline Manto azul celeste & Capa protetora & $\begin{array}{l}\text { Símbolo da esposa do } \\
\text { Espírito Santo } \\
\text { Representação do divino }\end{array}$ \\
\hline $\begin{array}{c}\text { Formação em semi-círculo } \\
\text { ou lunar }\end{array}$ & Semi-círculo & Volubilidade \\
\hline $\begin{array}{l}\text { Seres etéreos com asas nas } \\
\text { costas }\end{array}$ & Figuras fantasiadas & $\begin{array}{c}\text { Anjos } \\
\text { Representação do Bem } \\
\text { Intermediação divina } \\
\text { Proteção } \\
\end{array}$ \\
\hline Figura ajoelhada & Figura ajoelhada & $\begin{array}{c}\text { Oração } \\
\text { Humildade } \\
\text { Reverência/adoração }\end{array}$ \\
\hline
\end{tabular}


Sob o ponto de vista semântico, a imagem mostra a vitória ou superioridade do Bem (santa ou os nós desatados) sobre o Mal (serpente ou os nós atados) sob o esmagamento de seu pé. O sujeito da enunciação, ao estabelecer o contrato entre enunciador e enunciatário, faz um comunicado visual que deve levar o enunciatário a um dever-fazer (orar, desfazer os nós do pecado), a um querer não fazer (atar nós, pecar) e a um dever-saber (o que o anjo ajoelhado ensina). Em outras palavras: dever fazer oração à conversão e à crença no auxílio e intervenção de Maria; não querer fazer o pecado e dever saber da existência da serpente e sua tentação.

\section{O destinatário ideal - a recepção de Nossa Senhora Desatadora dos Nós}

O folheto de divulgação é direcionado a todos aqueles que possuem uma ligação cristã ou algum vínculo religioso ou ainda se encontram em situação de necessidade de apoio espiritual. Ao portar uma mensagem de fé, oferece uma espécie de conforto espiritual pela identificação com a figura de uma Santa - que é culturalmente conhecida como a 'mãe de Deus' - por ajudar pessoas com problemas familiares, conjugais, financeiros e profissionais.

\section{Conclusão}

Por meio da análise de um texto não-verbal, sob a perspectiva da semiótica visual greimasiana, associada ao percurso gerativo de sentido de um discurso, percebe-se que a imagem é um meio de expressão e de comunicação que nos vincula às tradições mais antigas e, portanto, históricas de nossa cultura. Nas palavras de Joly (2003, pp.135-136), "mesmo sua leitura mais ingênua e cotidiana mantém em nós uma memória que só exige ser um pouco reativada para se tornar mais uma ferramenta de autonomia do que de passividade..." Para sua compreensão e leitura, necessitam-se levar em conta alguns contextos da comunicação, da historicidade de sua interpretação e de suas especificidades culturais. Como discurso religioso, o folheto 
analisado produz uma espécie de ficção, pois se baseia em dogmas, afirmações não cỏmprováveis através de experiências e, em mitos, relatos de acontecimentos não documentados...

O discurso religioso cria uma convicção, não apoiada na razão, mas na intuição e na fé. Desta maneira, o folheto com a imagem de Nossa Senhora Desatadora dos Nós é um texto que propõe a ficção (parecer) para, em seguida, induzir a crença nesta ficção (fazer crer), processo a que se dá o nome de doutrinação ou catequese. $O$ objetivo ou objetivos dessa manifestação imagética parece ser pragmático: resolver os problemas, 'nós' e aflições do destinatário, bem como o de incutir nele o respeito, a adoração e a crença na divindade. A própria estrutura da mensagem orienta-se numa determinada organização de signos, , conferindo-lhe a identidade de um discurso persuasivo, isto é, com a intenção ou função de 'seduzir' o destinatário da mensagem. Neste caso, o canal, o veículo ou o medium gravura (santinho) impõe um perfil conativo ou apelativo a essa linguagem, centralizando-a no destinatário. O primeiro destes objetivos conativos traduz-se por um poder-fazer, ou seja, por tornar o fiel capaz de fazer algo que ele antes não podia. O segundo objetivo corresponde à imposição de uma obrigação, representada por um fazer dever fazer/não fazer, isto é, por fazer com que o fiel sinta-se na obrigação moral de fazer certas coisas (como orar, fazer promessa, desatar os nós do pecado) e de não fazer outras (pecar, não se converter, atar os nós da culpa) para cair nas graças divinas. Se a mensagem contém sentido, este tem de ser 'lido' por seu destinatário, por seu espectador que, em sua relação com o enunciado. ou neste caso, um texto visual, mobiliza diversos códigos, alguns quase universais (percepção), outros estruturados socialmente (analogia) e outros ainda ancorados no contexto sociocultural. Neste sentido, podese citar:

Se o texto é manifestação, produto material de um processo de significação e sentidos, se o texto é outro que o sujeito, em verdade, testemunhando não só sua ausência, como também a da coisa referente evidentemente existe um aquém e um além do texto que o 
$\therefore \quad$ it transcendem e constituem seu process̄o de enunciação, não podendo, porém, ser dele - texto - dissociados, não só porque impregnam or texto, tornando dificil esta segmentaçáo, como tàmbém porque uma dissociação forçada deixaria escapar muitos dos sentidos textuais. (Duarte, 2000, p.33) ic

Portanto; o quie se pretendeu demonstrar por meio de uma análise semiótica visual resume-se ao fato de que no percurso gerativo do sentido ou significado de uma mensagem, muitas vezes o visual determina uma contaminação do verbal pelo icôniço.: E que assim sendo, este artigo evidencia um provável percurso analítico, uma possível leitura semiótica, mas que não se pretende esgotada, visto que na leitura de obras abertas, as possibilidades são infinitas...

\section{Bibliografia}

AUMONT, J. 2004. A imagem. 8 ed., Trad. Estela dos Santos Abreu e Cláudio Santoro. Campinas: Papirus.

BARROS, D. L. P. de. 1990. Teoria semiótica do texto. São Paulo: Ática.

BARROS, D. L. P. de \& FIORIN, J. L (orgs.). 1999. Dialogismo, polifonia, intertextualidade. São Paulo: EDUSP.

BARTHES, R. 1990. O óbvio e o obtuso: ensaios críticos III. Rio de Janeiro: Nova Fronteira.

1964. A retórica da imagem. In: BARTHES, R 1984. O óbvio e o obtuso: ensaios críticos III. Lisboa: Edições 70 , p. 27437 .

BENJAMIN, W.1964. A obra de arte na época de sua reprodutibilidade técnica. In: LIMA, C. L (org.) 2000. Teoria da cultura de massa. São Paulo: Paz e Terra.

BERTRAND, D. 1985. L'espace et le sens. Paris-Amsterdam: Hadès/ Benjamin.

DUARTE, E.B. 2000. Considerações sobre a produção midiática. In: Mídias e processos de significação. Programa de PósGraduação em Comunicação. São Leopoldo: UNISINOS. 
FIORIN, J. L.1995. Semântica estrutural: o discurso fundador. In: OLIVEIRA; A.C. \&

FLOCH, J. M. 1985. Petites Mythologies de l'oeil e de l'espiritPour une semiothique plastique Paris-Amsterdam: HadèsBenjamin.

GREIMAS, A J. 1975. Sobre o sentido: ensaios semióticos. Petrópolis: Vozes.

2002. Da imperfeição. São Paulo: Hacker Editores.

GREIMAS A J: \& COURTÉS, J. 1979. Dicionário de semiótica. São Paulo: Cültrix.

JAKOBSON, R. 1969. Lingüistica e comunicação. Trad. De Izidoro Blikstein e José Paulo Paes. São Paulo: Cultrix.

JOLY, M. 2003. Introdução à análise da imagem. Campinas: Papirus. $6^{\mathrm{a}}$ ed.

LANDOWSKI, E. 1992. A sociedade refletida. Campinas: EDUCPontes.

1995. Do inteligivel ao sensivel: em torno da obra de A.J. Greimas. São Paulo: EDUC.

NASCIMENTO, G. C. do. 2002. A comunicação nas ciências da linguagem. In: Significação - Revista Brasileira de Semiótica. São Paulo: Annablume. jul -n. 17 (pp. 59-75).

PARISOT, D. 1989. La iglesia como espetáculo: la ultima tentación católica. Paris: Etudes.

SANTAELLA, L. \& NÖTH W. 2001. Imagem: cognição, semiótica, mídia. 3 ed., São Paulo: Iluminuras.

\section{Site consultado}

Disponível em: http://ositedossantos.vilabol.uol.com.br/ nsa_desatadora.html. Acessado em 16 de maio de 2005. 